\title{
Excessive greenhouse gas emissions from wastewater treatment plants by using the chemical oxygen demand standard
}

\author{
Zongqing $\mathrm{LV}^{1}$, Xiaoyu $\mathrm{SHAN}^{2}$, Xilin XIAO ${ }^{1}$, Ruanhong $\mathrm{CAI}^{1}$, \\ Yao ZHANG ${ }^{1 \dagger} \&$ Nianzhi JIAO ${ }^{1 *}$ \\ ${ }^{1}$ State Key Laboratory for Marine Environmental Science, Institute of Marine Microbes and Ecospheres, College of Ocean and Earth Sciences, \\ Xiamen University, Xiamen 361102, China; \\ ${ }^{2}$ School of Environment, Tsinghua University, Beijing 100084, China
}

Received May 20, 2021; revised August 12, 2021; accepted August 30, 2021; published online November 17, 2021

\begin{abstract}
Chemical oxygen demand (COD) is widely used as an organic pollution indicator in wastewater treatment plants. Large amounts of organic matter are removed during treatment processes to meet environmental standards, and consequently, substantial greenhouse gases (GHGs) such as methane $\left(\mathrm{CH}_{4}\right)$ are released. However, the COD indicator covers a great amount of refractory organic matter that is not a pollutant and could be a potential carbon sink. Here, we collected and analysed COD data from 86 worldwide municipal wastewater treatment plants (WWTPs) and applied a model published by the Intergovernmental Panel on Climate Change to estimate the emission of $\mathrm{CH}_{4}$ due to recalcitrant organic compound processing in China's municipal wastewater treatment systems. Our results showed that the average contribution of refractory COD to total COD removal was $55 \%$ in 86 WWTPs. The amount of $\mathrm{CH}_{4}$ released from the treatment of recalcitrant organic matter in 2018 could have been as high as 38.22 million tons of carbon dioxide equivalent, which amounts to the annual carbon sequestered by China's wetlands. This suggests that the use of COD as an indicator for organic pollution is undue and needs to be revised to reduce the emission of GHG. In fact, leaving nontoxic recalcitrant organic matter in the wastewater may create a significant carbon sink and will save energy during the treatment process, aiming at carbon neutrality in the wastewater treatment industry.
\end{abstract}

Keywords Chemical oxygen demand, Wastewater treatment, Recalcitrant dissolved organic matter, Greenhouse gas emission

Citation: Lv Z, Shan X, Xiao X, Cai R, Zhang Y, Jiao N. 2022. Excessive greenhouse gas emissions from wastewater treatment plants by using the chemical oxygen demand standard. Science China Earth Sciences, 65(1): 87-95, https://doi.org/10.1007/s11430-021-9837-5

\section{Introduction}

The driving force for climate change has been the emission of greenhouse gases (GHGs) since the industrial revolution (Hansen and Lacis, 1990; Lashof and Ahuja, 1990; Montzka et al., 2011), and wastewater treatment plants (WWTPs) are known to significantly contribute to these emissions (Koutsou et al., 2018; Nguyen et al., 2019). Since the environmental protection departments have established strict water quality standards for effluent from WWTPs (Union and

\footnotetext{
* Corresponding author (email: jiao@xmu.edu.cn)

$\dagger$ Corresponding author (email: yaozhang@xmu.edu.cn)
}

Parliament, 2013), to satisfy the environmental standards, organic matter and nutrients are removed from the wastewater (Ra et al., 2000; Zhang et al., 2020). This process produces methane $\left(\mathrm{CH}_{4}\right)$, carbon dioxide $\left(\mathrm{CO}_{2}\right)$, and nitrous oxide $\left(\mathrm{N}_{2} \mathrm{O}\right)$, which are then emitted to the atmosphere and contribute to climate change (Gupta and Singh, 2012; Poulsen and Hansen, 2009).

Direct $\mathrm{CO}_{2}$ emission comes from the mineralization of organics by microorganisms in the biological treatment process (Bao et al., 2015). $\mathrm{CH}_{4}$ is produced by anaerobic digestion as a consequence of sequential hydrolysis, acetogenesis, and methanogenesis of organic matter (Ziemiński 
and Frąc, 2012). The most commonly used biological nutrient removal techniques, such as anaerobic/anoxic/oxic $\left(\mathrm{A}_{2} \mathrm{O}\right)$ processes and sequencing batch reactor (SBR), have been found to generate large amounts of $\mathrm{CH}_{4}$ (Bao et al., 2016; Nguyen et al., 2019). Previous experiments have shown that $\mathrm{CH}_{4}$ emissions occur in all processing units of wastewater treatment (Liu et al., 2014), including both anaerobic and oxic tanks (Wang et al., 2011). The concentration of $\mathrm{CH}_{4}$ in the global atmosphere has increased from approximately 715 parts per billion (ppb, $1 \mathrm{ppb}=1 \mathrm{~nL} \mathrm{~L}^{-1}$ ) before the industrial era to $1872 \mathrm{ppb}$ in 2020 (https://www. esrl.noaa.gov). Furthermore, $\mathrm{CH}_{4}$ is equivalent to 28 times the global warming potential (GWP) of $\mathrm{CO}_{2}$ over a 100 -year time scale (IPCC, 2014). It has been reported that WWTPs can contribute up to $5 \%$ of global $\mathrm{CH}_{4}$ emissions (Chai et al., 2015). The GWP of $\mathrm{N}_{2} \mathrm{O}$ is much higher than that of $\mathrm{CH}_{4}$, and is 265 times that of $\mathrm{CO}_{2}$ (IPCC, 2014). It can be emitted as an intermediate product of denitrification, in which nitrate or nitrite is reduced by organic matter in wastewater (Hanaki et al., 1992; Wunderlin et al., 2012). It is estimated that the global emissions of $\mathrm{CH}_{4}$ and $\mathrm{N}_{2} \mathrm{O}$ from WWTPs will exceed 600 million tons and 100 million tons of $\mathrm{CO}_{2}$ equivalent $\left(\mathrm{CO}_{2} \mathrm{e}\right)$ by 2030 , respectively (Ragnauth et al., 2015). This indicates the urgency of reducing GHG emissions from wastewater treatment.

The concentration of organic matter in wastewater is commonly represented by chemical oxygen demand (COD), which includes biodegradable and nonbiodegradable organic components (Dulekgurgen et al., 2006). Another indicator widely used in water quality monitoring is biochemical oxygen demand (BOD), which represents the readily biodegradable fraction of the organic matter (Samudro and Mangkoedihardjo, 2010; Jouanneau et al., 2014). The minimization of COD and BOD is a major engineering goal to satisfy water quality standards (Cotillas et al., 2018; Freeman et al., 2018; Verma and Suthar, 2018). Biological treatments that rely on the catabolism and anabolism of microbes (including aerobic degradation and anaerobic digestion) are commonly conducted to decrease COD and BOD (de Souza et al., 2010; Mittal, 2011; Zhang et al., 2020). Moreover, anaerobic treatment is more commonly used to treat refractory organic matter (Barker et al., 1999). During anaerobic digestion, it has been reported that $80 \%$ of COD organics can be converted to gaseous $\mathrm{CH}_{4}$ (Foley et al., 2011).

It has been reported that a significant contributor to COD is recalcitrant dissolved organic matter (RDOM) (Jiao et al., 2021), which accounts for the majority of all dissolved organic matter and can act as an important carbon sink (Hansell, 2013; Jiao et al., 2010). RDOM exists in large quantities in influent wastewater, the wastewater treatment processes, and effluent wastewater (Archibald et al., 1998; Bockhorn et al., 2005; Jin et al., 2011; Lu et al., 2018). The relative contribution of refractory organic matter to the total organic matter has been reported to be as high as $91 \%$ in typical WWTPs in Switzerland (Kappeler and Gujer, 1992). This refractory organic matter can be used as a carbon sink in natural water environments; however, the anaerobic digestion process in wastewater treatment has high treatment efficiency for RDOM and thus releases vast amounts of $\mathrm{CH}_{4}$ (Chelliapan et al., 2012). Sweeping restrictions on COD of effluent from WWTPs will cause a large amount of RDOM to be removed and then release GHG.

BOD reflects the amount of oxygen consumed by biological respiration of organic matter in water bodies (Reynolds, 2002). Therefore, the difference between COD and BOD can be regarded as an approximation of nonbiodegradable RDOM in natural oxygenated waters (Jiao et al., 2021), which is here termed refractory COD (rCOD). The organic matter classified as rCOD can be degraded during anaerobic digestion processes that are usually carried out under severe conditions, such as extremely low $\mathrm{pH}$, high temperature, and high buffering capacity (Ward et al., 2008). To determine the mass of $\mathrm{CH}_{4}$ emissions by rCOD removal, in this study, we collected operational COD and BOD data from WWTPs across the world to calculate the relative contribution of rCOD to COD removal during municipal wastewater treatment. Furthermore, the annual potential of $\mathrm{CH}_{4}$ emissions from rCOD removal in wastewater treatment in China was estimated for 2017 and 2018. By investigating the GHG emissions caused by water quality monitoring indicators, this study provides a new perspective on the carbon neutrality of the wastewater treatment industry.

\section{Materials and methods}

\subsection{Data collected from worldwide WWTPs}

The Global Water Microbiome Consortium (http://gwmc.ou. edu) was launched in 2014 and makes available sample data from municipal wastewater treatment plants around the world (Wu et al., 2019). Using this website, we acquired a dataset from 100 municipal WWTPs, including actual flow rate, influent $\mathrm{BOD}\left(\mathrm{BOD}_{\text {in }}\right)$, effluent $\mathrm{BOD}\left(\mathrm{BOD}_{\mathrm{ef}}\right)$, influent $\mathrm{COD}\left(\mathrm{COD}_{\text {in }}\right)$, and effluent $\mathrm{COD}\left(\mathrm{COD}_{\mathrm{ef}}\right)$. Then we ruled out 14 cases where the BOD value was significantly greater than the COD value (data in doubt). The 86 WWTPs were selected from five continents, and the geographic distribution of the WWTPs is shown in Figure 1 and detailed in Appendix Table S1 (https://link.springer.com).

\subsection{Estimation of rCOD removal ratio in WWTPs}

BOD is generally reported as 5-day $\mathrm{BOD}\left(\mathrm{BOD}_{5}\right)$, 20-day $\mathrm{BOD}\left(\mathrm{BOD}_{20}\right)$, and ultimate $\mathrm{BOD}\left(\mathrm{BOD}_{\mathrm{u}}\right)$ (Bernardo et al., 2011). The obtained dataset is $\mathrm{BOD}_{5}$. $\mathrm{BOD}_{5}$ is approximately 


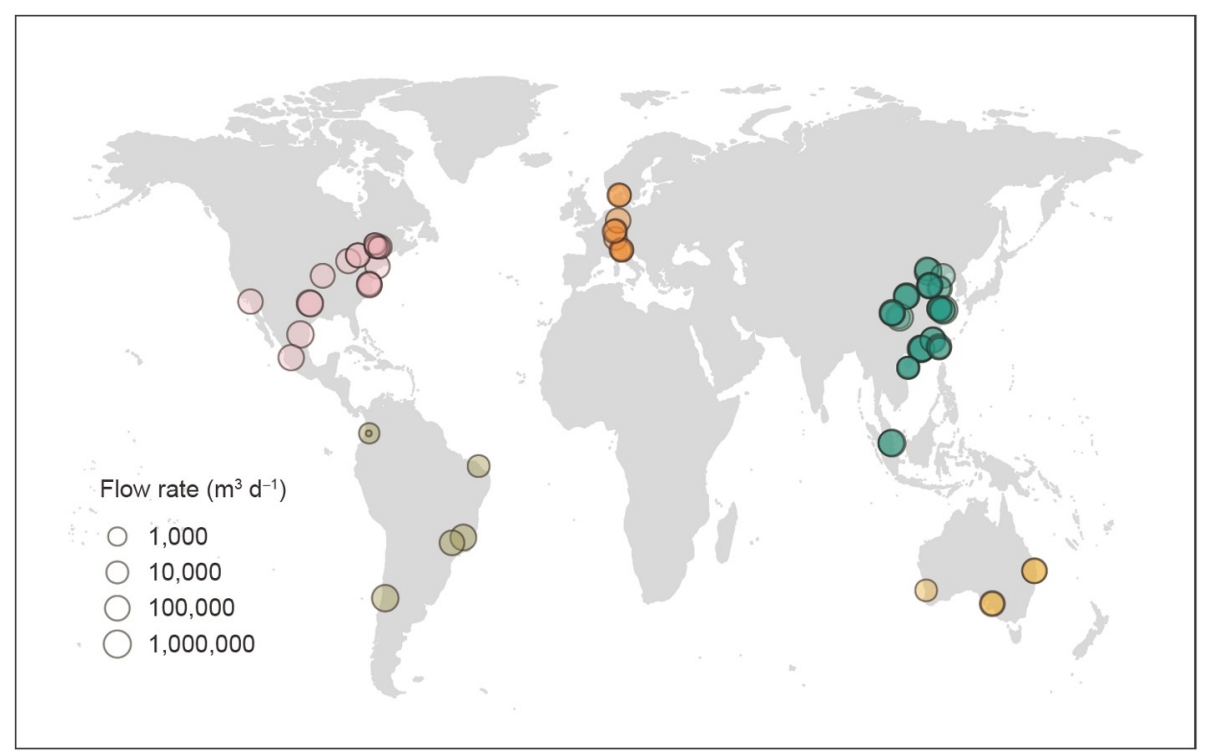

Figure 1 Geographic distribution of 86 municipal Wastewater treatment plants (WWTPs) globally sampled. Each circle represents a WWTP, whose flow rate $\left(\mathrm{m}^{3} \mathrm{~d}^{-1}\right)$ is proportional to the area of the circle. The sampling WWTPs cover five continents with different circle colours; Asia $(n=46)$, Europe $(n=9)$, North America $(n=20)$, South America $(n=6)$ and Australasia $(n=5)$. The map is adapted from Wu et al. (2019).

equal to $66 \%$ of the oxygen required for complete oxidation and decomposition (according to empirical values), whereas $\mathrm{BOD}_{\mathrm{u}}$ measures the amount of oxygen used by microorganisms over a much longer period of time (Huo et al., 2006; Makinia et al., 2002). Therefore, we estimated the $\mathrm{BOD}_{\mathrm{u}}$ of the WWTPs by dividing the reported $\mathrm{BOD}_{5}$ by $66 \%$ (Appendix Table S1). The difference between COD and $\mathrm{BOD}_{5}$ is defined as $\mathrm{rCOD}_{5}$, and the difference between COD and $\mathrm{BOD}_{\mathrm{u}}$ is defined as $\mathrm{rCOD}_{\mathrm{u}} \cdot \mathrm{rCOD}_{\mathrm{u}}$ represents the more recalcitrant organic matter. COD removal can be calculated using the COD of the influent and effluent. The formula for calculating rCOD removal is as follows:

$$
\begin{aligned}
\mathrm{rCOD}_{\text {Removal }} & =\mathrm{rCOD}_{\text {in }}-\mathrm{rCOD}_{\text {ef }} \\
& =\left(\mathrm{COD}_{\text {in }}-\mathrm{BOD}_{\text {in }}\right)-\left(\mathrm{COD}_{\mathrm{ef}}-\mathrm{BOD}_{\mathrm{ef}}\right),
\end{aligned}
$$

where $\mathrm{rCOD}_{\text {in }}$ is the $\mathrm{rCOD}$ of the influent wastewater and $\mathrm{rCOD}_{\mathrm{ef}}$ is the rCOD of the effluent wastewater.

Then, we performed a cross validation-based intercept-free least square regression of $\mathrm{rCOD}$ concentrations against COD concentrations in the influent, effluent, and during removal. For each regression, cross validation was performed 999 times, in which half the samples $(n=43)$ were used as the training set and the other half $(n=43)$ samples were used as the validation set. The cross-validation $R^{2}$ was then calculated as:

$R^{2}=1-\frac{\operatorname{RSS}}{\operatorname{TSS}}=1-\frac{\sum_{i=1}^{n}\left(y_{i}-\widehat{y}_{i}\right)^{2}}{\sum_{i=1}^{n}\left(y_{i}-\bar{y}\right)^{2}}$,

where RSS is the residual sum of squares; TSS is the total sum of squares; $\widehat{y}_{i}$ is the fitted value for the $i$ th sample in the validation set; $y_{i}$ is the observed value for the $i$ th sample in the validation set and $\bar{y}$ is the average of observed values across all samples in the validation set.

\subsection{Calculation model of conversion between COD and $\mathrm{CH}_{4}$}

To estimate the $\mathrm{CH}_{4}$ emissions by the removal of rCOD in worldwide WWTPs, data from 86 WWTPs were used to establish a model. The data of COD removal and $\mathrm{CH}_{4}$ emissions from WWTPs released by the Chinese government were used to verify whether the model is applicable. Therefore, we estimated the annual removal of rCOD in Chinese municipal wastewater treatment by obtaining the average proportion of rCOD in COD removal from the 86 WWTPs.

The annual rCOD removal of China's municipal wastewater treatment was estimated using eq. (3):

$\Delta \mathrm{rCOD}=\Delta \mathrm{COD} \times$ average removal ratio,

where $\triangle \mathrm{rCOD}$ is the annual rCOD removal in China's municipal wastewater treatment systems (million tons); $\triangle \mathrm{COD}$ is the total COD removal in China's municipal wastewater treatment systems (million tons), which was 11.80 and 12.41 million tons in 2017 and 2018, respectively (http://www. mee.gov.cn); the average removal ratio is estimated from section $2.2(=\mathrm{rCOD}$ removal/COD removal from the 86 WWTPs $\times 100 \%$ ).

The maximum potential of $\mathrm{CH}_{4}$ emissions $\left(\mathrm{ECH}_{4}\right)$ by $\triangle \mathrm{rCOD}$ from wastewater was estimated using eq. (4) (IPCC, 2006):

$\mathrm{ECH}_{4}=\Delta \mathrm{rCOD} \times \mathrm{EF} \times \mathrm{MCF}-\mathrm{R}$,

where $\triangle \mathrm{rCOD}$ is defined above; $\mathrm{EF}$ is the maximum $\mathrm{CH}_{4}$ production/emission factor $\left(0.25 \mathrm{~kg} \mathrm{CH}_{4} / \mathrm{kg} \mathrm{COD}\right)$; $\mathrm{MCF}$ is a 
$\mathrm{CH}_{4}$ correction factor for the type of process employed for wastewater treatment (shown in Appendix Table S2); and R is the mass of $\mathrm{CH}_{4}$ captured for combustion and/or flaring at the plant or transfer out of the plant $(\mathrm{kg})$. Here, only the maximum potential was considered, and subsequent processing (e.g., $\mathrm{CH}_{4}$ recovery) was not included.

\section{Results and discussion}

\subsection{Contribution of rCOD to COD}

The concentrations of BOD and rCOD in the influent and effluent of global WWTPs are shown in Figure 2. We found that the removal of BOD was always accompanied by the removal of rCOD. The BOD loss can be easily explained by the catabolism and anabolism of microbes, whereas the accompanying rCOD loss may be explained by excessive sludge digestion or advanced elimination of pollutants to meet strict COD discharge standards. In addition, a small proportion of inorganic ions could contribute to both COD (such as nitrite, sulphate, and ferrous ions) (Kylefors et al., 2003; Samudro and Mangkoedihardjo, 2010) and BOD (such as sulphide and ferrous ions) (Hudson et al., 2008; Yu et al., 2016).

To quantitively characterize the relationship between COD and $\mathrm{rCOD}$, we performed an intercept-free linear regression of $\mathrm{rCOD}\left(\mathrm{rCOD}_{5}\right.$ and $\left.\mathrm{rCOD}_{\mathrm{u}}\right)$ against $\mathrm{COD}$ (Figure 3$)$. It was found that influent $\mathrm{rCOD}_{5}$ contributed $56 \%$ of the influent COD (cross-validation $R^{2}=0.95, p<10^{-16}$ ) (Figure 3a), indicating a predominant proportion of $\mathrm{rCOD}_{5}$ in the $\mathrm{COD}$ of the influent. Effluent $\mathrm{rCOD}_{5}$ contributed $74 \%$ of the effluent $\operatorname{COD}\left(R^{2}=0.78, p<10^{-16}\right)$ (Figure $3 \mathrm{c}$ ), which supports the notion that the biodegradability of wastewater decreases after treatment. Taking $\mathrm{rCOD}_{5}$ removal as the difference between influent $\mathrm{rCOD}_{5}$ and effluent $\mathrm{rCOD}_{5}$, we found that the overall contribution of $\mathrm{rCOD}_{5}$ removal to COD removal was $55 \%\left(R^{2}=0.93, p<10^{-16}\right)$ (Figure $\left.3 \mathrm{~b}\right)$. This indicates that the per unit concentration of COD removal represented 0.55 units of $\mathrm{rCOD}_{5}$ removal in these WWTPs. The estimated $\operatorname{rCOD}_{\mathrm{u}}$ accounted for $33 \%\left(R^{2}=0.75, p<10^{-16}\right)$ of the influent COD (Figure 3d), 61\% $\left(R^{2}=0.67, p<10^{-16}\right)$ of the effluent COD (Figure $3 \mathrm{f}$ ), and $32 \%\left(R^{2}=0.15, p<10^{-16}\right)$ of COD removal (Figure $3 \mathrm{e}$ ). At least $32 \%$ of the removed COD originated from organic matter that was resistant to aerobic
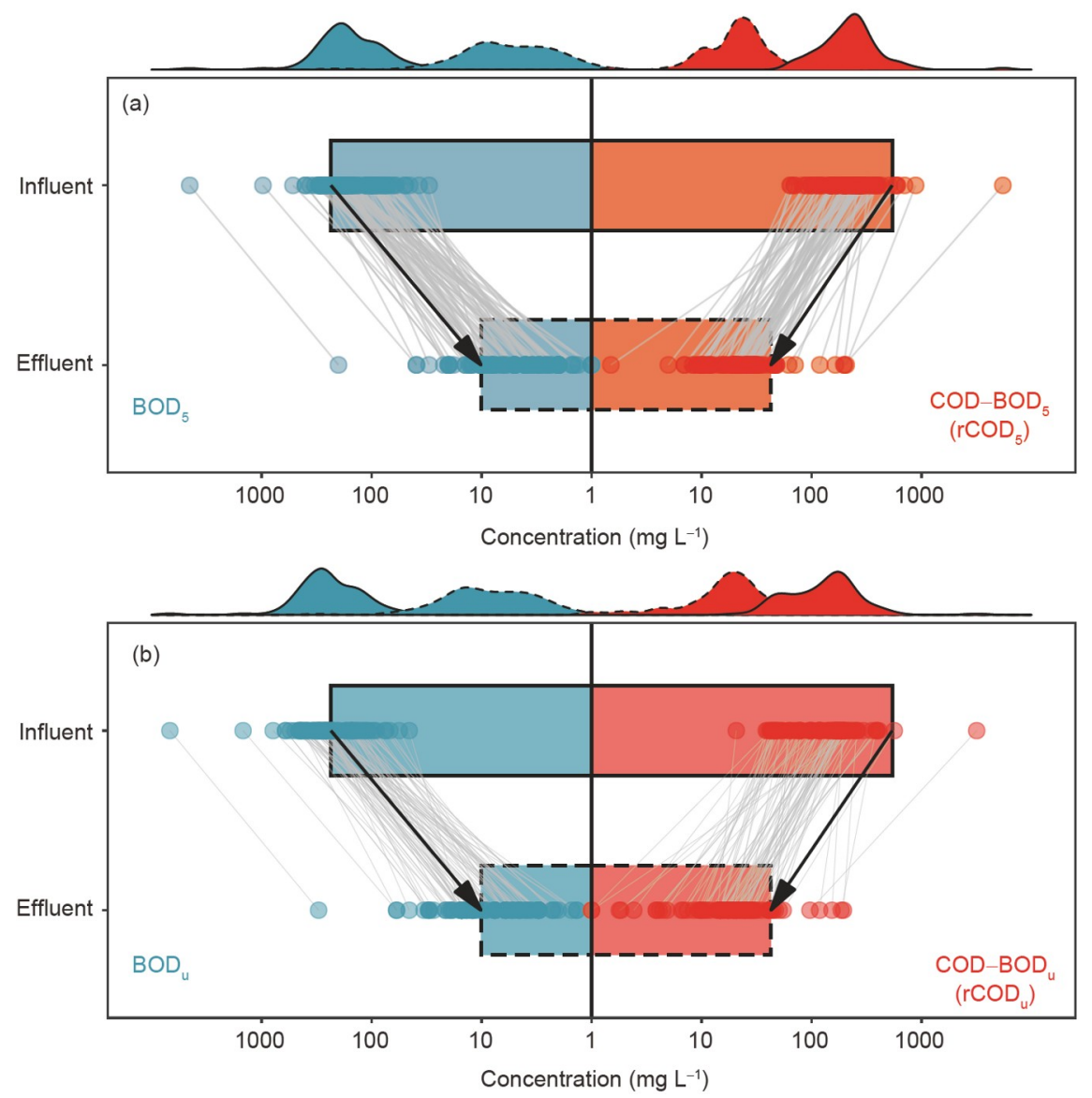

Figure 2 The removal of wastewater COD comprises BOD (blue) and rCOD (red), which is defined as COD-BOD. (a) and (b) show the concentration changes of $\mathrm{BOD}_{5}$ and $\mathrm{rCOD}_{5}$ and $\mathrm{BOD}_{\mathrm{u}}$ and $\mathrm{rCOD}_{\mathrm{u}}$, respectively. Influent and effluent concentrations from the same WWTP are matched by a grey line. Bar plots in the bottom panel show the average influent concentrations (solid line) and effluent concentrations (dashed lines) across all sampled WWTPs. Curves in the top panel show the density distribution of influent and effluent concentrations of BOD and rCOD. 


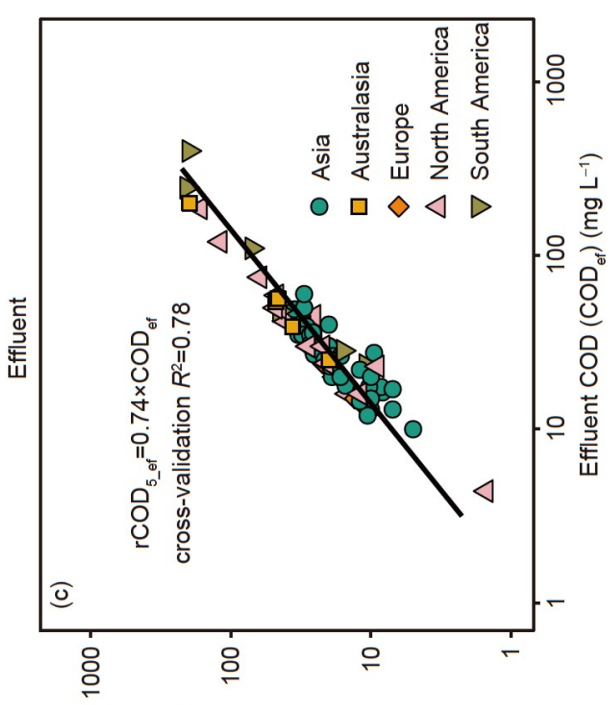

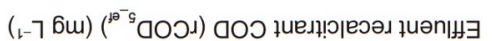

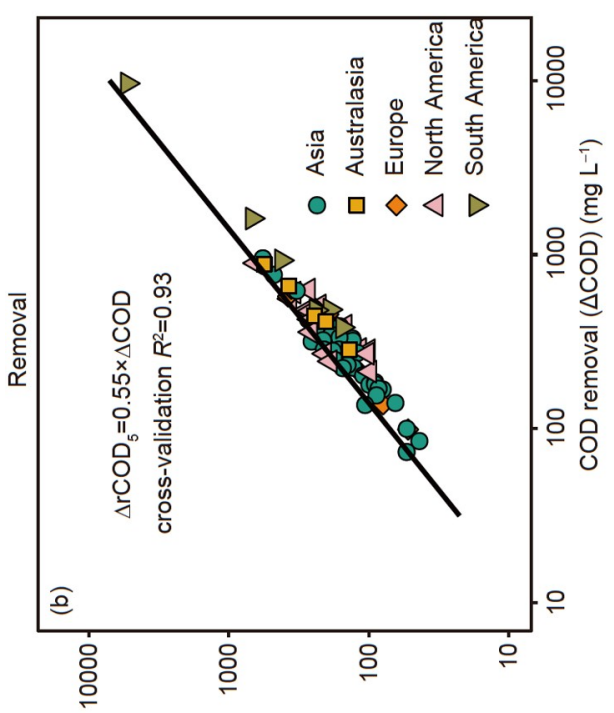

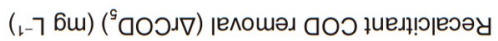

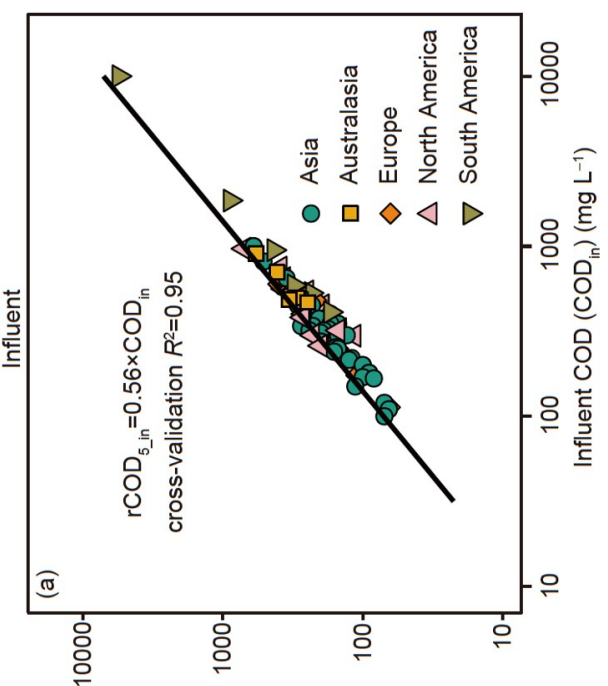

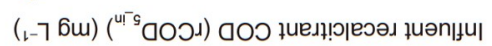

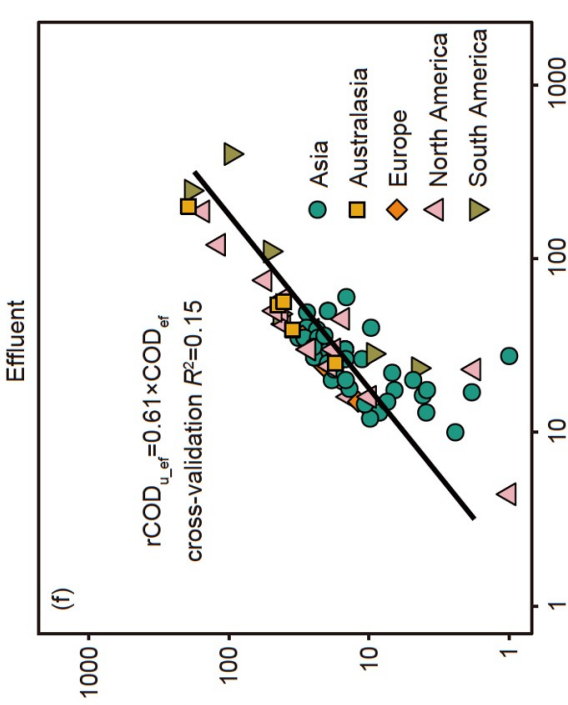

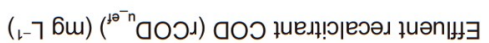

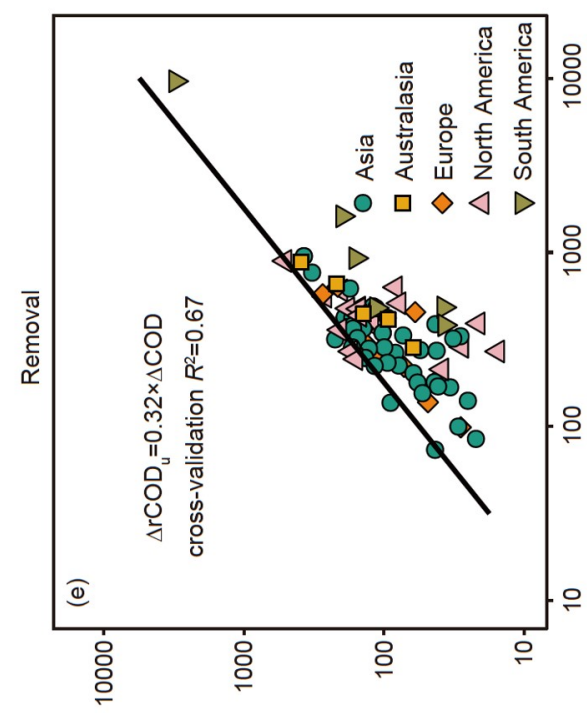

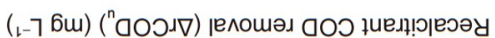

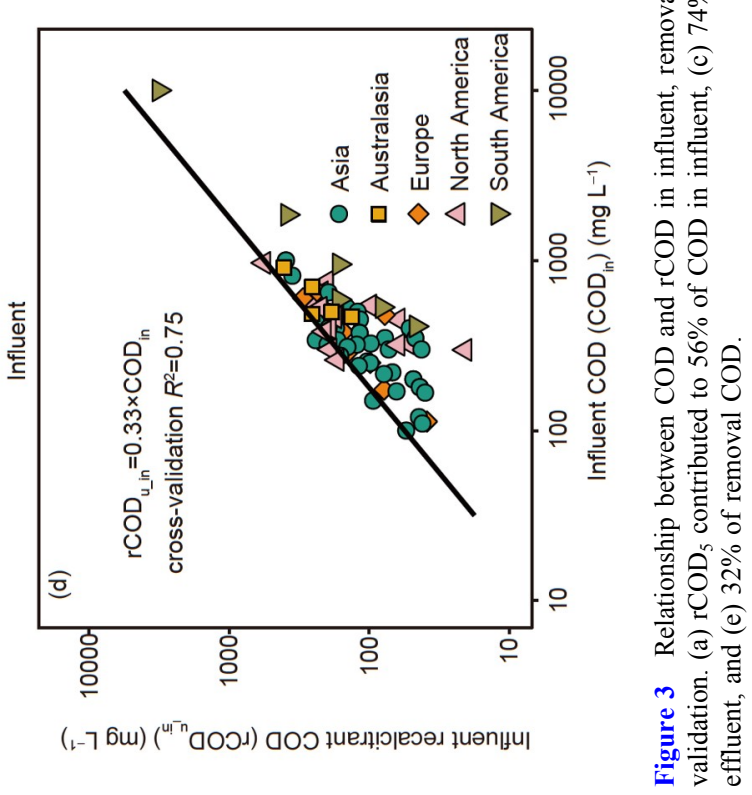


degradation. When applying this regression model to China's annual COD removal, it was estimated that the $\triangle \mathrm{rCOD}_{5}$ and $\triangle \mathrm{rCOD}_{\mathrm{u}}$ removed by municipal wastewater treatment in 2017 were 6.49 and 3.78 million tons, and in 2018, they were 6.83 and 3.97 million tons, respectively.

Figure 3 a shows that BOD accounted for less than half the COD when the COD of the influent was divided into BOD and rCOD. This indicated that approximately half of the organic matter in wastewater cannot be rapidly degraded by aerobic microbes in natural water environments. This refractory organic matters are mainly composed of high-molecular-weight humic substances and low-molecular-weight microbial products ( $\mathrm{Lu}$ et al., 2018). Specifically, humic substances and fulvic acid compounds are not only present largely in the influent wastewater but are also a major byproduct of both aerobic and anaerobic biological treatment of wastewater (Guo et al., 2011). It was estimated that the microbial products measured in terms of COD were an average of $2.2 \%$ of the $\mathrm{COD}_{\text {in }}$ (Ince et al., 2000). These microbialderived products could resist biodegradation and could be stored in natural environments for a long time (Jiao et al., 2010). However, in wastewater treatment, these products are further removed in the subsequent denitrification and phosphate removal processes, which promotes the production of GHG (Lemaire et al., 2006; Yan et al., 2020). Different from natural conditions, wastewater treatment processes are usually carried out under specific and severe conditions (Ward et al., 2008), resulting in RDOM removal during wastewater treatment.

\subsection{Estimated mass of GHG converted by $\triangle \mathrm{rCOD}$}

It was found that anaerobic processes played an important role in the degradation of refractory compounds (Wang et al., 2012). To estimate the potential maximum emission due to the removal of refractory organic matter, we assumed that the rCOD was removed anaerobically, although the majority of WWTPs (especially in China) do not utilize only anaerobic treatment processes (Fang et al., 2016). The maximum MCF (0.8; Appendix Table S2) was used to estimate $\mathrm{CH}_{4}$ emissions from Chinese municipal WWTPs (Table 1). For a simpler comparison, $\mathrm{CH}_{4}$ was converted to $\mathrm{CO}_{2} \mathrm{e}(\mathrm{GWP}=28)$. If $\mathrm{CH}_{4}$ recovery was not considered, the maximum potential for the conversion of $\Delta \mathrm{rCOD}_{5}$ to $\mathrm{CH}_{4}\left(\mathrm{CO}_{2} \mathrm{e}\right)$ was 1.30 (36.34) and 1.37 (38.22) million tons in 2017 and 2018, respectively. The maximum potential for conversion of $\Delta \mathrm{rCOD}_{\mathrm{u}}$ to $\mathrm{CH}_{4}\left(\mathrm{CO}_{2} \mathrm{e}\right)$ was 0.76 (21.15) and 0.79 (22.24) million tons in 2017 and 2018, respectively.

The calculated mass of $\mathrm{CH}_{4}$ could be overestimated since anaerobic treatment (major process) is not the sole treatment process of rCOD and a small part of rCOD was treated by intensive post-treatments with less $\mathrm{CH}_{4}$ released, such as aerobic polishing, ozonisation, electrocoagulation and elec- tron beam irradiation (Barker et al., 1999; Deogaonkar et al., 2019; Kallas and Munter, 1994; Makwana and Ahammed, 2017). In addition, we did not take the recovery of $\mathrm{CH}_{4}$ into account for the estimation of maximal $\mathrm{CH}_{4}$ emission potential. Previous studies have estimated that energy recovery from $\mathrm{CH}_{4}$ may compensate for half of the consumed energy in the wastewater treatment process and thus reduce indirect $\mathrm{CO}_{2}$ emissions by at least 50\% (dos Santos et al., 2016; Hao et al., 2014, 2015). This can help approach to its target regarding carbon neutrality in WWTPs.

To confirm the reliability of the model, the estimated data were compared with the official data released by the Chinese government. When the $\mathrm{rCOD}_{5}$ removal ratio $(55 \%)$ was applied to China's wastewater treatment in 2014, $\Delta \mathrm{rCOD}_{5}$ would have contributed 1.49 million tons of the officially released total $\mathrm{CH}_{4}$ emission data (2.71 million tons) (http://www.mee.gov.cn), which was even higher than the estimated value in 2018 ( 1.37 million tons). This also reflects, to a certain extent, that the recovery and utilization of $\mathrm{CH}_{4}$ as an energy source in China is still in urgent need of development.

Table 1 shows that the removal of rCOD in 2018 could result in the emission of approximately 22.24-38.22 million tons of $\mathrm{CO}_{2} \mathrm{e}$. Compared with the energy, transportation, and other carbon-intensive industries, the cost of emission reduction within wastewater treatment is low and the benefit of emission reduction is obvious (Zhang et al., 2015). The wastewater treatment industry has already been listed as a priority sector for reducing emissions and achieving carbon neutrality in many countries (Mo and Zhang, 2012). If measured according to the algorithm of the forestry carbon sink ( $\mathrm{Li}, 2007)$, the $\mathrm{CO}_{2}$ emitted from the annual removal of rCOD would require afforestation of approximately 2.5 to 4 million hectares to offset, which would cost 31-53 billion dollars. Furthermore, these GHG emissions could account for $50-86 \%$ of the annual carbon sequestered by China's wetlands (44.54 million tons) in 2014 (http://www.mee.gov. cn). Wetlands are important carbon sinks in the Earth's ecological system, and they play an important role in absorbing atmospheric GHG and preserving recalcitrant organic matter (Chen et al., 2017; Mitsch et al., 2013).

Exacerbating $\mathrm{GHG}$ emissions is the contribution of $\mathrm{N}_{2} \mathrm{O}$, a significant product of COD removal. $\mathrm{N}_{2} \mathrm{O}$ is thought to be an inevitable intermediate product in the process of wastewater nitrogen removal because of incomplete denitrification. Limits on COD have led to more $\mathrm{N}_{2} \mathrm{O}$ production (Shannon et al., 2008), and previous studies have found that a low $\mathrm{COD} / \mathrm{N}$ ratio, which represents a shortage of carbon, will cause denitrifying bacteria to use internal carbon sources for denitrification (Geng et al., 2010; Wu et al., 2009). This can lead to the accumulation of nitrite and then cause more $\mathrm{N}_{2} \mathrm{O}$ to be produced, which will exacerbate GHG emissions (Rodriguez-Garcia et al., 2012). 
Table 1 Estimation of the annual greenhouse gas (GHG) emission potential stemming from recalcitrant chemical oxygen demand (rCOD) removal in Chinese municipal wastewater treatment in 2017 and 2018

\begin{tabular}{ccccc}
\hline \multirow{2}{*}{ Year } & \multicolumn{4}{c}{ GHG emissions from anaerobic digestion ${ }^{\mathrm{a})}$ (million tons) } \\
\cline { 2 - 5 } & $\mathrm{ECH}_{4}{ }^{\mathrm{b})}$ & $\mathrm{CO}_{2} \mathrm{e}^{\mathrm{b}, \mathrm{c})}$ & $\mathrm{CH}_{4}{ }^{\mathrm{d})}$ & $\mathrm{ECO}_{2} \mathrm{e}^{\mathrm{c}, \mathrm{d})}$ \\
\hline 2017 & 1.30 & 36.34 & 0.76 & 21.15 \\
2018 & 1.37 & 38.22 & 0.79 & 22.24 \\
\hline
\end{tabular}

a) Does not include $\mathrm{CH}_{4}$ recovery, b) converted from estimated $\triangle \mathrm{rCOD}_{5}$, c) $\mathrm{CH}_{4}$ was converted to $\mathrm{CO}_{2} \mathrm{e}(\mathrm{GWP}=28)$ (IPCC, 2014), d) converted from estimated $\triangle \mathrm{rCOD}_{\mathrm{u}}$

\subsection{The balance between GHG emissions and waste- water treatment efficiency}

Future wastewater treatment should pursue not only the goal of reducing organic pollutants but also a balance between organic matter removal efficiency and reduction of GHG emissions. Using the classical COD indicator has disadvantages, and in fact, a high COD value does not necessarily correspond to the poor water quality. There are many natural water environments with a richness of RDOM that are of high water quality, while the COD does not meet the standards (Aoki et al., 2004; Jiao et al., 2021; Räike et al., 2012). It has been reported that effluent wastewater from paper mills contains large amounts of lignin-based recalcitrant organic material that can contribute to COD but is not acutely toxic and is very similar to natural organic matter (Archibald et al., 1998). Additionally, it was reported that a high COD value may not indicate the eutrophication of the water body (Guo et al., 2017).

With the development of human society, the content of DOM in water will inevitably increase (Sepp et al., 2018), and if DOM is removed indiscriminately, carbon will be emitted to the atmosphere, aggravating climate change. With the improvement of wastewater treatment technology, more organic matter will be removed to meet the COD standard. Therefore, if the use of the COD indicator is not revised, a high COD removal ratio will be accompanied by higher levels of direct GHG emissions. The water treatment industry should set up improved water quality monitoring indicators, such as indicators distinguishing the characteristics and biodegradability of wastewater organic matter as well as their fates in natural environments and indicators focusing on inorganic ions and organics that are hazardous to humans and other organisms. The improved water quality monitoring indicators could help preserve nontoxic RDOM as carbon storage, whereby carbon neutrality of the wastewater treatment industry could be achieved in a more economical way.

\section{Conclusion}

The wastewater treatment industry is an important part of the global carbon cycle with significant climate change impacts. When organic matter is removed from wastewater, large amounts of $\mathrm{CO}_{2}, \mathrm{~N}_{2} \mathrm{O}$, and $\mathrm{CH}_{4}$ are released, resulting in the greenhouse effect. This study highlights that COD is not a suitable water quality monitoring indicator. Under present regulations for COD in wastewater effluent, a large amount of RDOM is removed, and GHGs are emitted to the atmosphere as a result. The theoretical carbon emission potential of recalcitrant organic matter processed by China's municipal WWTPs in 2018 could be as high as 38.22 million tons of $\mathrm{CO}_{2} \mathrm{e}$, which is equivalent to the annual amount of carbon sequestered in Chinese wetlands. Therefore, the COD indicator standards applied in the wastewater treatment industry should be revised. More work should be done in the future to improve water quality monitoring indicators to achieve a balance between water quality improvement and GHG emission reduction, aiming at carbon neutrality in the wastewater treatment industry.

Acknowledgements We thank Dr. Daliang Ning, Dr. Bing Zhang, Prof. Jizhong Zhou and Prof. Yunfeng Yang for their support with the GWMC dataset. This work was supported by the National Basic Science Center of National Natural Science Foundation of China, National Key $R \& D$ Program (Grant No. 2016YFA0601400), and the National Natural Science Foundation of China (Grant Nos. 91751207 and 41861144018).

Open Access This article is licensed under a Creative Commons Attribution 4.0 International License, which permits use, sharing, adaptation, distribution and reproduction in any medium or format, as long as you give appropriate credit to the original author(s) and the source, provide a link to the Creative Commons licence, and indicate if changes were made. The images or other third party material in this article are included in the article's Creative Commons licence, unless indicated otherwise in a credit line to the material. If material is not included in the article's Creative Commons licence and your intended use is not permitted by statutory regulation or exceeds the permitted use, you will need to obtain permission directly from the copyright holder. To view a copy of this licence, visit http://creativecommons.org/licenses/by/4.0/.

\section{References}

Aoki S, Fuse Y, Yamada E. 2004. Determinations of humic substances and other dissolved organic matter and their effects on the increase of COD in Lake Biwa. Anal Sci, 20: 159-164

Archibald F, Roy-Arcand L, Méthot M, Valeanu L. 1998. Recalcitrant organic compounds (chemical oxygen demand sources) in biologically treated pulp and paper mill effluents: Their fate and environmental impact in receiving waters. Water Environ Res, 70: 1314-1326

Bao Z, Sun S, Sun D. 2015. Characteristics of direct $\mathrm{CO}_{2}$ emissions in four full-scale wastewater treatment plants. Desalin Water Treat, 54: 10701079

Bao Z, Sun S, Sun D. 2016. Assessment of greenhouse gas emission from $\mathrm{A} / \mathrm{O}$ and SBR wastewater treatment plants in Beijing, China. Int Biodeter Biodegr, 108: 108-114

Barker D J, Mannucchi G A, Salvi S M L, Stuckey D C. 1999. Characterisation of soluble residual chemical oxygen demand (COD) in anaerobic wastewater treatment effluents. Water Res, 33: 24992510

Bernardo M, Santos A, Cantinho P, Minhalma M. 2011. Biodegradation rate constants in different NF/UF fractions of cork processing waste- 
waters. Desalin Water Treat, 29: 264-270

Bockhorn H, Braun A M, Frimmel F H, Reimert R, Syldatk C. 2005. Das Engler-Bunte-Institut der Universität Karlsruhe (TH) in den Jahren 2003/2004. GWF, 146: 432-452

Chai C, Zhang D, Yu Y, Feng Y, Wong M. 2015. Carbon footprint analyses of mainstream wastewater treatment technologies under different sludge treatment scenarios in China. Water, 7: 918-938

Chelliapan S, Mahat S B, Din M, Yuzir A, Othman N. 2012. Anaerobic digestion of paper mill wastewater. Iran J Energy Environ, 3: 85-90

Chen H, Popovich S, McEuen A, Briddell B. 2017. Carbon and nitrogen storage of a restored wetland at Illinois' Emiquon preserve: Potential for carbon sequestration. Hydrobiologia, 804: 139-150

Cotillas S, Llanos J, Cañizares P, Clematis D, Cerisola G, Rodrigo M A, Panizza M. 2018. Removal of Procion Red MX-5B dye from wastewater by conductive-diamond electrochemical oxidation. Electrochim Acta, 263: 1-7

Deogaonkar S C, Wakode P, Rawat K P. 2019. Electron beam irradiation post treatment for degradation of non biodegradable contaminants in textile wastewater. Radiat Phys Chem, 165: 108377

dos Santos I F S, Vieira N D B, Barros R M, Filho G L T, Soares D M, Alves L V. 2016. Economic and $\mathrm{CO}_{2}$ avoided emissions analysis of WWTP biogas recovery and its use in a small power plant in Brazil. Sust Energy Technol Assess, 17: 77-84

Dulekgurgen E, Doğruel S, Karahan O, Orhon D. 2006. Size distribution of wastewater COD fractions as an index for biodegradability. Water Res, 40: 273-282

Fang F, Qiao L L, Cao J S, Li Y, Xie W M, Sheng G P, Yu H Q. 2016. Quantitative evaluation of $\mathrm{A}^{2} \mathrm{O}$ and reversed $\mathrm{A}^{2} \mathrm{O}$ processes for biological municipal wastewater treatment using a projection pursuit method. Sep Purif Technol, 166: 164-170

Foley J, Yuan Z, Keller J, Senante E, Chandran K, Willis J, Shah A, van Loosdrecht M, van Voorthuizen E. 2011. $\mathrm{N}_{2} \mathrm{O}$ and $\mathrm{CH}_{4}$ emission from wastewater collection and treatment systems. Technical Report. Global Water Research Coalition

Freeman A I, Surridge B W J, Matthews M, Stewart M, Haygarth P M. 2018. New approaches to enhance pollutant removal in artificially aerated wastewater treatment systems. Sci Total Environ, 627: 11821194

Geng J, Wang Y, Zhang Z. 2010. N2O production and mechanism in recently developed biological nitrogen removal processed (in Chinese). Acta Sci Circumstant, 30: 1729-1738

Guo J, Peng Y, Guo J, Ma J, Wang W, Wang B. 2011. Dissolved organic matter in biologically treated sewage effluent (BTSE): Characteristics and comparison. Desalination, 278: 365-372

Guo W, Yang F, Li Y, Wang S. 2017. New insights into the source of decadal increase in chemical oxygen demand associated with dissolved organic carbon in Dianchi Lake. Sci Total Environ, 603: 699-708

Gupta D, Singh S K. 2012. Greenhouse gas emissions from wastewater treatment plants: A case study of Noida. J Water Sustainability, 2: 131139

Hanaki K, Hong Z, Matsuo T. 1992. Production of nitrous oxide gas during denitrification of wastewater. Water Sci Technol, 26: 1027-1036

Hansell D A. 2013. Recalcitrant dissolved organic carbon fractions. Annu Rev Mar Sci, 5: 421-445

Hansen J E, Lacis A A. 1990. Sun and dust versus greenhouse gases: An assessment of their relative roles in global climate change. Nature, 346: 713-719

Hao X, Liu R, Hu Y. 2014. Creation of evaluation method of "carbon neutral" for wwtps and analysis of a practical case (in Chinese). China Water Wastewater, 20: 2

Hao X, Liu R, Huang X. 2015. Evaluation of the potential for operating carbon neutral WWTPs in China. Water Res, 87: 424-431

Hudson N, Baker A, Ward D, Reynolds D M, Brunsdon C, Carliell-Marquet C, Browning S. 2008. Can fluorescence spectrometry be used as a surrogate for the Biochemical Oxygen Demand (BOD) test in water quality assessment? An example from South West England. Sci Total Environ, 391: 149-158
Huo J, Jiang Y, Seaver W L, Robinson R B, Cox C D. 2006. Statistically based design of wastewater treatment plants (WWTPs) using Monte Carlo simulation of Activated Sludge Model No. 1 (ASM1). World Environmental \& Water Resources Congress

Ince B K, Ince O, Sallis P J, Anderson G K. 2000. Inert COD production in a membrane anaerobic reactor treating brewery wastewater. Water Res, 34: 3943-3948

IPCC. 2006. IPCC guidelines for national greenhouse gas inventories, Prepared by the National Greenhouse Gas Inventories Programme. In: Egglesto H S, Buendia L, Miwa K, Ngara T, Tanabe K, eds. Published, IGES, Japan

IPCC. 2014. Climate change 2014: Synthesis report. In: Pachauri R K, Meyer L A, eds. Contribution of Working Groups I, II and III to the Fifth Assessment Report of the Intergovernmental Panel on Climate Change. IPCC, Geneva. 151

Jiao N, Herndl G J, Hansell D A, Benner R, Kattner G, Wilhelm S W, Kirchman D L, Weinbauer M G, Luo T, Chen F, Azam F. 2010. Microbial production of recalcitrant dissolved organic matter: Long-term carbon storage in the global ocean. Nat Rev Microbiol, 8: 593-599

Jiao N, Liu J, Edwards B, Lv Z, Cai R, Liu Y, Xiao X, Wang J, Jiao F, Wang R, Huang X, Guo B, Sun J, Zhang R, Zhang Y, Tang K, Zheng Q, Azam F, Batt J, Cai W J, He C, Herndl G J, Hill P, Hutchins D, LaRoche J, Lewis M, MacIntyre H, Polimene L, Robinson C, Shi Q, Suttle C A, Thomas H, Wallace D, Legendre L. 2021. Correcting a major error in assessing organic carbon pollution in natural waters. Sci Adv, 7: eabc7318

Jin G, Bao G, Feng S, Fang F. 2011. Effluent organic matter removal during advanced wastewater treatment process: O3-BAC and AC/O3-BAC. Second International Conference on Mechanic Automation \& Control Engineering

Jouanneau S, Recoules L, Durand M J, Boukabache A, Picot V, Primault Y, Lakel A, Sengelin M, Barillon B, Thouand G. 2014. Methods for assessing biochemical oxygen demand (BOD): A review. Water Res, 49: 62-82

Kallas J, Munter R. 1994. Post treatment of pulp and paper industry wastewater's using oxidation and adsorption processes. Water Sci Technol, 29: 259-272

Kappeler J, Gujer W. 1992. Estimation of kinetic parameters of heterotrophic biomass under aerobic conditions and characterization of wastewater for activated sludge modelling. Water Sci Technol, 25: 125-139

Koutsou O P, Gatidou G, Stasinakis A S. 2018. Domestic wastewater management in Greece: Greenhouse gas emissions estimation at country scale. J Cleaner Prod, 188: 851-859

Kylefors K, Ecke H, Lagerkvist A. 2003. Accuracy of COD test for landfill leachates. Water Air Soil Pollution, 146: 153-169

Lashof D A, Ahuja D R. 1990. Relative contributions of greenhouse gas emissions to global warming. Nature, 344: 529-531

Lemaire R, Meyer R, Taske A, Crocetti G R, Keller J, Yuan Z. 2006. Identifying causes for $\mathrm{N}_{2} \mathrm{O}$ accumulation in a lab-scale sequencing batch reactor performing simultaneous nitrification, denitrification and phosphorus removal. J Biotechnol, 122: 62-72

Li N. 2007. China Forest Carbon Sequestration (in Chinese). Beijing: China Forestry Publishing House. 200

Liu Y, Cheng X, Lun X, Sun D. 2014. $\mathrm{CH}_{4}$ emission and conversion from $\mathrm{A}^{2} \mathrm{O}$ and SBR processes in full-scale wastewater treatment plants. $\mathrm{J}$ Environ Sci, 26: 226-232

Lu D, Xiao K, Chen Y, Soh Y N A, Zhou Y. 2018. Transformation of dissolved organic matters produced from alkaline-ultrasonic sludge pretreatment in anaerobic digestion: From macro to micro. Water Res, 142: $138-146$

Makinia J, Swinarski M, Dobiegala E. 2002. Experiences with computer simulation at two large wastewater treatment plants in northern Poland. Water Sci Technol, 45: 209-218

Makwana A R, Ahammed M M. 2017. Electrocoagulation process for the post-treatment of anaerobically treated urban wastewater. Separation Sci Tech, 52: 1412-1422 
Mitsch W J, Bernal B, Nahlik A M, Mander Ü, Zhang L, Anderson C J, Jørgensen S E, Brix H. 2013. Wetlands, carbon, and climate change. Landscape Ecol, 28: 583-597

Mittal A. 2011. Biological wastewater treatment. Water Today, 1: 32-44

Mo W, Zhang Q. 2012. Can municipal wastewater treatment systems be carbon neutral? J Environ Manage, 112: 360-367

Montzka S A, Dlugokencky E J, Butler J H. 2011. Non- $\mathrm{CO}_{2}$ greenhouse gases and climate change. Nature, 476: 43-50

Nguyen T K L, Ngo H H, Guo W, Chang S W, Nguyen D D, Nghiem L D, Liu Y, Ni B, Hai F I. 2019. Insight into greenhouse gases emissions from the two popular treatment technologies in municipal wastewater treatment processes. Sci Total Environ, 671: 1302-1313

Poulsen T G, Hansen J A. 2009. Assessing the impacts of changes in treatment technology on energy and greenhouse gas balances for organic waste and wastewater treatment using historical data. Waste Manage Res, 27: 861-870

Ra C, Lo K, Shin J, Oh J, Hong B. 2000. Biological nutrient removal with an internal organic carbon source in piggery wastewater treatment. Water Res, 34: 965-973

Ragnauth S A, Creason J, Alsalam J, Ohrel S, Petrusa J E, Beach R H. 2015. Global mitigation of non- $\mathrm{CO}_{2}$ greenhouse gases: Marginal abatement costs curves and abatement potential through 2030. J Integrative Environ Sci, 12: 155-168

Räike A, Kortelainen P, Mattsson T, Thomas D N. 2012. 36 year trends in dissolved organic carbon export from Finnish rivers to the Baltic Sea. Sci Total Environ, 435-436: 188-201

Reynolds D M. 2002. The differentiation of biodegradable and non-biodegradable dissolved organic matter in wastewaters using fluorescence spectroscopy. J Chem Technol Biotechnol, 77: 965-972

Rodriguez-Garcia G, Hospido A, Bagley D M, Moreira M T, Feijoo G. 2012. A methodology to estimate greenhouse gases emissions in Life Cycle Inventories of wastewater treatment plants. Environ Impact Assessment Rev, 37: 37-46

de Souza S M A G U, Bonilla K A S, de Souza A A U. 2010. Removal of COD and color from hydrolyzed textile azo dye by combined ozonation and biological treatment. J Hazard Mater, 179: 35-42

Samudro G, Mangkoedihardjo S. 2010. Review on BOD, COD and BOD/ COD ratio: A triangle zone for toxic, biodegradable and stable levels. Int J Acad Res, 2: 235-239

Sepp M, Koiv T, Noges P, Noges T. 2018. Do organic matter metrics included in lake surveillance monitoring in Europe provide a broad picture of brownification and enrichment with oxygen consuming substances? Sci Total Environ, 610-611: 1288-1297

Shannon M A, Bohn P W, Elimelech M, Georgiadis J G, Mariñas B J, Mayes A M. 2008. Science and technology for water purification in the coming decades. Nature, 452: 301-310
Union E, Parliament E. 2013. Regulation (EU) Nr. 575/2013 of the European Parliament and of the Council

Verma R, Suthar S. 2018. Performance assessment of horizontal and vertical surface flow constructed wetland system in wastewater treatment using multivariate principal component analysis. Ecol Eng, 116: 121126

Wang J, Zhang J, Xie H, Qi P, Ren Y, Hu Z. 2011. Methane emissions from a full-scale A/A/O wastewater treatment plant. Bioresource Tech, 102: $5479-5485$

Wang Z, Xu X, Gong Z, Yang F. 2012. Removal of COD, phenols and ammonium from Lurgi coal gasification wastewater using $\mathrm{A}^{2} \mathrm{O}-\mathrm{MBR}$ system. J Hazard Mater, 235: 78-84

Ward A J, Hobbs P J, Holliman P J, Jones D L. 2008. Optimisation of the anaerobic digestion of agricultural resources. Bioresource Tech, 99: 7928-7940

Wu J, Zhang J, Jia W, Xie H, Gu R R, Li C, Gao B. 2009. Impact of COD/ $\mathrm{N}$ ratio on nitrous oxide emission from microcosm wetlands and their performance in removing nitrogen from wastewater. Bioresource Tech, 100: $2910-2917$

Wu L, Ning D, Zhang B, Li Y, Zhang P, Shan X, Zhang Q, Brown M R, Li Z, Van Nostrand J D, Ling F, Xiao N, Zhang Y, Vierheilig J, Wells G F, Yang Y, Deng Y, Tu Q, Wang A, Zhang T, He Z, Keller J, Nielsen P H, Alvarez P J J, Criddle C S, Wagner M, Tiedje J M, He Q, Curtis T P, Stahl D A, Alvarez-Cohen L, Rittmann B E, Wen X, Zhou J. 2019. Global diversity and biogeography of bacterial communities in wastewater treatment plants. Nat Microbiol, 4: 1183-1195

Wunderlin P, Mohn J, Joss A, Emmenegger L, Siegrist H. 2012. Mechanisms of $\mathrm{N}_{2} \mathrm{O}$ production in biological wastewater treatment under nitrifying and denitrifying conditions. Water Res, 46: 1027-1037

Yan N, Ck A, Rdw C, Dcsa D. 2020. Composition and biotransformational changes in soluble microbial products (SMPs) along an anaerobic baffled reactor (ABR). Chemosphere, 254: 126775

Yu X, Xu R, Wei C, Wu H. 2016. Removal of cyanide compounds from coking wastewater by ferrous sulfate: Improvement of biodegradability. J Hazard Mater, 302: 468-474

Zhang B, Ning D, Yang Y, Van Nostrand J D, Zhou J, Wen X. 2020. Biodegradability of wastewater determines microbial assembly mechanisms in full-scale wastewater treatment plants. Water Res, 169: 115276

Zhang X, Cao J, Li J, Deng S, Zhang Y, Wu J J R, Reviews S E. 2015. Influence of sewage treatment on China's energy consumption and economy and its performances. Renew Sust Energ Rev, 49: 10091018

Ziemiński K, Frąc M. 2012. Methane fermentation process as anaerobic digestion of biomass: Transformations, stages and microorganisms. Afr J Biotechnol, 11: 4127-4139 